\title{
HONORARIUM
}

\section{The 2011 recipient of the Brady Medal: Dr John A. Barron}

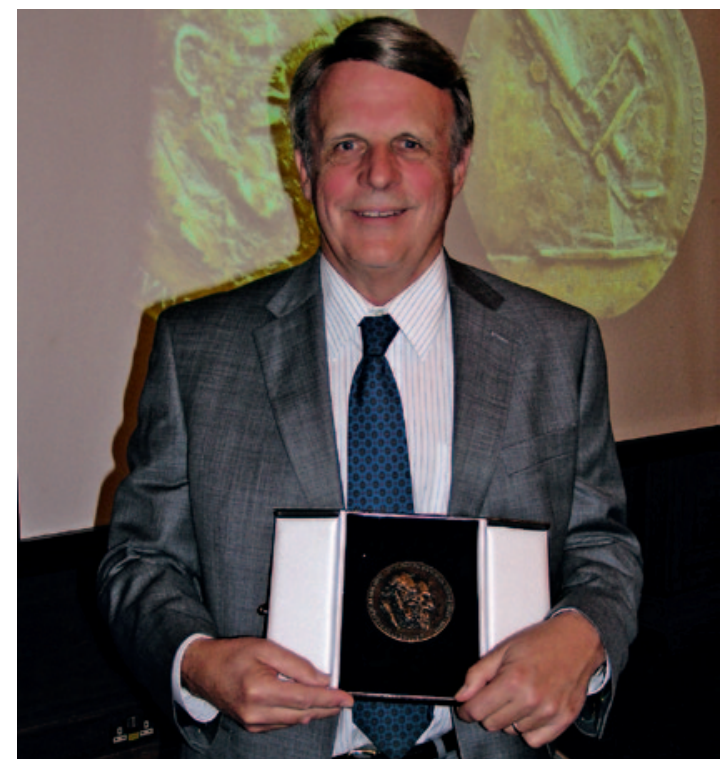

Dr John Barron is an internationally renowned expert in marine diatom taxonomy, biostratigraphy, palaeoceanography and palaeoclimatology. He graduated from the University of California, Los Angeles (UCLA) in 1969 with a BS Geology degree and completed his doctoral research in Geology at UCLA, as a student of Helen N. Tappan, in 1974. John took up a position as a research geologist/micropalaeontologist for the United States Geological Survey (USGS) in Menlo Park, California in 1974 where he remains today as a Supervisory Research Geologist within the Volcano Science Center. Notably, he is the Survey's internationally recognized expert on the climate of the past 15000 years in the North Pacific area and on the climatic and glacial history of Antarctica during the past 65 million years. In 1984, John was elected a Fellow of the Geological Society of America and, in 1986, he was presented the Charles Schuchert Award by the Paleontological Society for excellence and promise in palaeontology. In 1994 he was awarded a US Department of Interior Meritorious Service Award by the USGS and, in 2005, was elected a Fellow of the California Academy of Sciences.

John is the leading world authority on Cenozoic marine diatom biostratigraphy and evolution, having established and revised many biostratigraphic zonations during his $40+$ year career, and described numerous new diatom species, such as Actinocyclus fryxellae, Thalassiosira gersondei and T. mahoodii (Baldauf \& Barron, 1991). He has repeatedly demonstrated the value of marine diatoms for solving a range of important geological problems for the entire diatom fossil record (Cretaceous to Holocene), particularly in areas such as the Southern Ocean where other microfossil groups are rare. A creative thinker, from the time of his first publication on Neogene ocean palaeotemperatures (Barron, 1973) John was, in many respects, a leader in the field of palaeoceanography. He has, over the years, changed the way micropalaeontologists and palaeoceanographers view marine diatoms as valuable proxies and biostratigraphic tools. Indeed, few other scientists in the field have made such an outstanding and long-lasting contribution to the subject area. He has also demonstrated breadth across the siliceous microfossil spectrum by contributing to the use of silicoflagellates in biostratigraphy (first in Barron, 1976) and palaeoclimatology (e.g. Barron \& Bukry, 2007).

Many of John's advances in Cenozoic marine diatom biostratigraphy have resulted from his active sea-going research career, undertaking research cruises to the Bering Sea and Gulf of California with the USGS, and as a shipboard scientist on Deep Sea Drilling Project (DSDP) and Ocean Drilling Program (ODP) cruises. John was directly involved as a micropalaeontologist on DSDP Leg 57 (Japan) in 1977, Leg 63 (California) in 1978, Leg 85 (equatorial Pacific) in 1982, ODP Leg 145 (North Pacific) in 1992 and, notably, as Co-Chief Scientist on ODP Leg 119 (Antarctic Margin) in 1987/88. As Co-Chief he was co-responsible for selecting and supervising 30 international scientists, editing their papers in the Science Results volume (Barron et al., 1991a), and first-authored two syntheses for that volume (Barron et al., 1991b, c). ODP Leg 119, the first Antarctic drilling cruise in the Indian Ocean region, proved that the initial expansion of the Antarctic Ice Sheet (c. $34 \mathrm{Ma}$ ) was continental in scale. Its scientific findings have formed, and continue to form, the basis for subsequent international drilling projects by the ODP and its successor the Integrated Ocean Drilling Program (IODP) as well as the ongoing Antarctic Geological Drilling (ANDRILL).

Further, John has been involved in numerous other research cruises as a shore-based scientist and served as expert on the climate of high latitude areas and siliceous biostratigraphy for the international ODP Ocean History Panel from 1990 to 1993 and, as such, was actively involved in evaluating numerous deep-sea drilling proposals for ODP. From 1995 to 1997 he was the USGS representative on the United States Science Advisory Committee (USSAC) to ODP, a National Science Foundation (NSF) committee that oversaw the activity of ODP. Professionally, John has undertaken active leadership roles not only within the ODP, but also within his position at the USGS, being Assistant Team Leader for Climate Change from 1998 until the present and, demonstrating his diversity, as a member of the USGS Volcano Science Center. Since 1995, John has led the efforts of the Earth Surface Dynamics Program (now the Climate and Land Use Change, Research and Development Program) to collect and evaluate high-resolution climate records along the Pacific coasts of North America between the Gulf of Alaska and the Gulf of California (Mexico). Currently, as Project Chief of the Holocene Climates of the USGS Pacific Coasts Project, he supervises scientists from the Western Earth Surface Processes and Coastal Marine Geology programmes in documenting the natural climate variability of the past 15000 years and determining its causes. Recently, he served as the USGS representative for the US Climate Change Science Program Assessment Product 3.4 on Abrupt Climate Change.

During his career to date, John has published over 200 peerreviewed scientific publications (76 as first author), which includes an impressive range of journal papers $(55+)$, book chapters $(45+)$, professional and technical papers $(10+)$ in the fields of marine diatom taxonomy, biostratigraphy (e.g. Barron, 2003), biochronology (e.g. Barron, 2005), palaeoceanography and palaeoclimatology (e.g. Barron et al., 2003; Lyle et al., 2008) to more applied themes such as the investigation of hydrocarbon-bearing lithologies, notably the 
Miocene Monterey Formation (e.g. Barron, 1986; 1987). Not only a diatom specialist, John is also renowned for his deep understanding of global climate change and global palaeoceanography. We particularly highlight his work on the evolution of marine diatoms and their application to palaeoenvironmental studies (Barron \& Baldauf, 1995; Barron, 2003), the history and development of the Antarctic ice sheet (Barron et al., 1991c; Barron, 1996), the history of modern climate change and its impacts along the Pacific coasts of North America (Barron et al., 2003; Barron \& Bukry, 2007; Barron \& Anderson, 2011), and on how tectonism, including mountain building, and climate have shaped the deposition of rocks in California (Barron, 1986; 1998). Notably, he developed marine diatoms as the principal biostratigraphic tool for dating the main petroleum-producing rock unit in California, the Monterey Formation. In addition to this notable achievement, John co-discovered the presence of world-wide Neogene hiatuses in deep-sea sedimentation and recognized their climatic and tectonic significance (Keller \& Barron, 1983; Barron, 1989). His papers on this subject remain as the most highly cited papers on deep-sea hiatuses and continue to serve as the basis of international research efforts that aim to understand patterns of deepsea sedimentation and the erosive effects of deep-sea bottom waters.

It is clear that John has dedicated his career not solely to research advances as specialist and as palaeoceanographer, but also to the education of students and scientists who are new to diatom micropalaeontology (e.g. Barron, 1985; Barron \& Baldauf, 1989; 1995). Many of his papers have been in both of our filing cabinets for many years and are still routinely used to train current generations of diatom micropalaeontologists globally. In addition, over the years, John has served as a supervisor examiner for $13 \mathrm{PhD}$ dissertations that deal with diatoms as biostratigraphic and paleoceanographic tools. He has also mentored numerous students in $\mathrm{PhD}$ and Master's studies on a wide variety of topics at both US and international (UK, France, Australia, India) universities. Not only a prolific author, role-model, mentor and advocator of our science, one of John's other guises includes being on the editorial board for a variety of international journals, including Micropaleontology, Marine Micropaleontology, Palaeogeography, Palaeoclimatology, Palaeoecology, and Diatom Research. Further, as part of his role at the USGS, John has been actively engaged in promoting the public understanding of science for many years.

John has had eight diatoms named for him: Hyalodiscus barronii Hajós, 1979; Craspedodiscus barronii Bukry, 1984; Actinocyclus barronii Radionova, 1985; Azpeitia barronii Fryxell \& Watkins, 1986; Trinacria barronii Sims \& Ross, 1988; Nitzschia barronii Gersonde, 1990; Denticulopsis barronii Yanagisawa, 1990; Bogorovia barronii Yanagisawa, 1995. This demonstrates the high regard in which he is held by the marine diatomist community. Passionate about his work (but refreshingly self-effacing) he has made excellent and countless important contributions across numerous facets of marine diatom micropalaeontology (and silicoflagellates). His legacy (being an active researcher means more to come!) will be lasting as scholars continue to cite his works both in the classroom and in their own research. Inspirational for the quality of his work and enthusiasm for the subject, he has encouraged many younger scientists into the field of diatom research, and siliceous microfossil workers routinely seek his advice in many areas of the subject, valuing his broad knowledge and experience. For all of these reasons, John deserves the highest recognition for his outstanding contribution to micropalaeontology and, as such, is a fully deserving recipient of the fifth Brady Medal of The Micropalaeontological Society.

\section{REFERENCES}

Baldauf, J.G. \& Barron, J.A. 1991. Diatom biostratigraphy: Kerguelen Plateau and Prydz Bay regions of the Southern Ocean. In Barron, J., Larsen, B. et al. (Eds), Proceedings of the Ocean Drilling Program, Scientific Results, Leg 119. Ocean Drilling Program, College Station, TX, 547-598.

Barron, J.A. 1973. Late Miocene-Early Pliocene paleotemperatures for California from marine diatom evidence. Palaeogeography, Palaeoclimatology, Palaeoecology, 14: 277-291.

Barron, J.A. 1976. Marine diatom and silicoflagellate biostratigraphy of the type Delmontian Stage and type Bolivina obliqua Zone, California. US Geological Survey Journal of Research, 4: 339-352.

Barron, J.A. 1985. Miocene to Holocene planktic diatoms. In Bolli, H.M., Saunders, J.B. \& Perch-Nielsen, K. (Eds), Plankton Stratigraphy, Volume 2. Cambridge University Press, Cambridge, 763-809.

Barron, J.A. 1986. Paleoceanographic and tectonic controls on deposition of the Monterey Formation and related siliceous rocks in California. Palaeogeography Palaeoclimatology Palaeoecology, 53: 27-45.

Barron, J.A. 1987. Diatomite: environmental and geologic factors affecting its distribution. In Hein, J.R. (Ed.), The Genesis of Ores and Petroleum Associated with Sedimentary Siliceous Deposits. Van Nostrand-Reinhold, New York, 164-178.

Barron, J.A. 1989. The late Cenozoic stratigraphic record and hiatuses of the northeast Pacific: Results from the Deep Sea Drilling Project. In Winterer, E.L., Hussong, D.M. \& Decker, R.W. (Eds), The Eastern Pacific Ocean and Hawaii, The Geology of North America, Volume N. Geological Society of America, Boulder, Colorado, 311-322.

Barron, J.A. 1996. Diatom constraints on the position of the Antarctic Polar Front in the middle part of the Pliocene. Marine Micropaleontology, 27: 195-213.

Barron, J.A. 1998. Late Neogene changes in diatom sedimentation in the North Pacific. Journal of Asian Earth Sciences, 16: 85-95.

Barron, J.A. 2003. Planktonic marine diatom record of the past 18 m.y.: appearances and extinctions in the Pacific and Southern Oceans. Diatom Research, 18: 203-224.

Barron, J.A. 2005. Diatom biochronology of the early Miocene of the equatorial Pacific. Stratigraphy, 2: 281-309.

Barron, J.A. \& Anderson, L. 2011. Enhanced Late Holocene ENSO/PDO expression along the margins of the eastern North Pacific. Quaternary International, 235: 3-12.

Barron, J.A. \& Baldauf, J. 1989. Tertiary cooling steps and paleoproductivity as reflected by diatoms and biosiliceous sediments. In Berger, W.H., Smetacek, V.S. \& Wefer, G. (Eds), Productivity of the Ocean: Present and Past. J. Wiley and Sons, Chichester, 341-354.

Barron, J.A. \& Baldauf, J.G. 1995. Cenozoic marine diatom biostratigraphy and applications to palaeoclimatology and paleoceanography. In Blome, C.D. et al. (Eds), Siliceous Microfossils. Paleontological Society Short Courses in Paleontology, 8: 107-118.

Barron, J.A. \& Bukry, D. 2007. Solar forcing of the Gulf of California climate during the past two thousand years suggested by diatoms and silicoflagellates. Marine Micropaleontology, 62: 115-139.

Barron, J., Larsen, B. \& 28 others. 1991a. Proceedings of the Ocean Drilling Program, Scientific Results 119. Ocean Drilling Program, College Station, TX, 1003 pp.

Barron, J.A., Baldauf, J.G., Barrera, E. et al. 1991b. Biochronologic and magnetochronologic synthesis of Leg 119 sediments from the Kerguelen Plateau and Prydz Bay, Antarctica. In Barron, J., Larsen, B. et al., Proceedings of the Ocean Drilling Program, Scientific Results 119. Ocean Drilling Program, College Station, TX, 813-847.

Barron, J., Larsen, B. \& Baldauf, J.G. 1991c. Evidence for late Eocene to early Oligocene Antarctic glaciation and observations on late Neogene glacial history of Antarctica: results from Leg 119. In Barron, J., Larsen, B. et al., Proceedings of the Ocean Drilling Program, Scientific Results 119. Ocean Drilling Program, College Station, TX, 869-891.

Barron, J.A., Heusser, L., Herbert, T. \& Lyle, M. 2003. High-resolution climatic evolution of coastal northern California during the past 16,000 years. Paleoceanography, 18: DOI: 1029/2002PA000768.

Keller, G. \& Barron, J.A. 1983. Paleoceanographic implications of Miocene deep-sea hiatuses. Geological Society of America Bulletin, 94: 590-613.

Lyle, M., Barron, J., Bralower, T.J. et al. 2008. Pacific Ocean and Cenozoic evolution of climate. Reviews of Geophysics, 46, RG2002, DOI: 10.1029/2005RG000190.

\section{Jennifer Pike}

School of Earth and

Ocean Sciences, Cardiff University,

Main Building, Park Place,

Cardiff CF10 3AT, UK

(e-mail: pikej@cardiff.ac.uk)
Catherine E. Stickley

Department of Geology,

University of Tromsø,

N-9037 Tromsø, Norway 